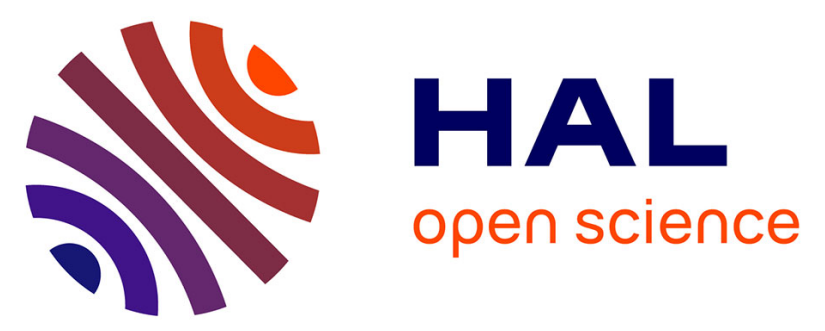

\title{
"Gueule cassée" (facial injuries): a 3D paleotraumatology study and facial approximation of a Napoleonic soldier who died in 1812 at Königsberg during the Russian Campaign
}

Dany Coutinho Nogueira, Bruno Dutailly, Florent Comte, Alexandr Vasil'Iev, Alexander Khokhlov, Tatiana Shvedchikova, Natalia Berezina, Alexandra Buzhilova, Olivier Dutour, Hélène Coqueugniot

\section{- To cite this version:}

Dany Coutinho Nogueira, Bruno Dutailly, Florent Comte, Alexandr Vasil'Iev, Alexander Khokhlov, et al.. "Gueule cassée" (facial injuries): a 3D paleotraumatology study and facial approximation of a Napoleonic soldier who died in 1812 at Königsberg during the Russian Campaign. International Journal of Osteoarchaeology, 2019, 29 (2), pp.191-197. 10.1002/oa.2728 . hal-02150398

\author{
HAL Id: hal-02150398 \\ https://hal.science/hal-02150398
}

Submitted on 16 Dec 2020

HAL is a multi-disciplinary open access archive for the deposit and dissemination of scientific research documents, whether they are published or not. The documents may come from teaching and research institutions in France or abroad, or from public or private research centers.
L'archive ouverte pluridisciplinaire HAL, est destinée au dépôt et à la diffusion de documents scientifiques de niveau recherche, publiés ou non, émanant des établissements d'enseignement et de recherche français ou étrangers, des laboratoires publics ou privés. 
"Gueule cassée" (facial injuries): a 3D paleo-traumatology study and facial approximation of a Napoleonic soldier who died in 1812 at Königsberg during the Russian Campaign

Dany COUTINHO NOGUEIRA ${ }^{\mathrm{a}, \mathrm{b}^{*}}$, Bruno DUTAILLY ${ }^{\mathrm{b}}$, Florent COMTE $^{\mathrm{c}}$, Alexander VASILYEV $^{\mathrm{d}}$, Alexander KHOKHLOV ${ }^{\mathrm{e}}$, Tatiana SHVEDCHIKOVA ${ }^{\mathrm{e}}$, Natalia BEREZINA ${ }^{\mathrm{f}}$, Alexandra BUZHILOVA ${ }^{\mathrm{f}}$, Olivier DUTOUR ${ }^{\mathrm{a}, \mathrm{b}, \mathrm{g}}$, Hélène COQUEUGNIOT ${ }^{\mathrm{a}, \mathrm{b}, \mathrm{h}}$

a - EPHE - PSL University - Chaire d'Anthropologie biologique Paul Broca, Paris France

b - PACEA, UMR5199 CNRS, University of Bordeaux, MCC; LabEx Sciences archéologiques de Bordeaux, (ANR-10-LABX-52) Pessac, France

c - Ausonius, UMR 5607 CNRS - University Bordeaux Montaigne; LabEx Sciences archéologiques de Bordeaux, (ANR-10-LABX-52) Pessac, France

d - Department of Radiology, Lomonosov Moscow State University, Russia

e - Institute of Archaeology, Russian Academy of Sciences, Moscow, Russia

f - Research Institute and Museum of Anthropology, Lomonosov Moscow State University, Russia

g - Department of Anthropology, University of Western Ontario, Canada

h - Department of Human Evolution, Max Planck Institute for Evolutionary Anthropology, Leipzig, Germany

*Corresponding author: dany.coutinho-nogueira@etu.ephe.psl.eu

\section{Highlight}

- Paleo-traumatology of a saber-wounded Napoleonic soldier (Russian Campaign)

- Virtual reconstruction of the cranium and mandible

- Facial approximation to account for injuries

\section{Abstract}

The invasion of Russia by the Napoleonic Grande Armée was a complete disaster. The French army was decimated during the retreat from Russia. Thousands of victims were buried in mass graves located near several cities during the retreat. One of these mass graves was discovered in in the center of Kaliningrad (formerly Königsberg), presently the most occidental oblast of the Russian Federation. Some skeletons revealed evidence of violence related traumatic injuries. Among them, the skeleton $\mathrm{C} 2$ belonged to a young male, who had 
suffered a serious injury to the lower face. The state of post-traumatic remodeling indicated survival of about 2 months (between more than 6 weeks and less than 3 months).

The 3D reconstruction of the mandible and the maxilla contributed additional information about the injury, its cause and treatment. This permitted pre-traumatic reconstruction of the viscerocranium and mandible through the application of two new techniques: virtual osteotomy and virtual bone transplant from another individual and perform an approximation of the face (to recreate the soft tissues) of this unidentified soldier using AFA3D software. These results highlight the use of 3D methods in paleopathology and forensic anthropology to reconstruct traumatic facial injuries and the pre-traumatic facial appearance.

\section{Keywords}

Paleotraumatology, paleopathology, 3D reconstruction, facial approximation, Gueule cassée

\section{Introduction}

In 1812, in response to Russia's withdrawal from the continental blockade of the United Kingdom and to liberate Poland, Napoleon I invaded Russia. This military campaign was a disaster and the Grande Armée was decimated. Napoleon was forced to retreat from Moscow which has been set on fire by its inhabitants. The French defeat at the Battle of Berezina (November 1812) brought an end to this disastrous campaign. However, the extremely cold Russian winter; infectious diseases, in particular typhus; and starvation killed more soldiers than did the battles against the Russian troops (de Beauchamp, 1825; Noël, 1895; Boudon, 2012). Hundred thousand victims were buried in mass graves that marked the passage of increasingly desperate troops (Signoli et al., 2004, 2008; Dutour et al., 2014, 2015). Königsberg, capital city of Eastern Prussia, today known as Kaliningrad, Russian Federation, was one of the places where the survivors of the Grand Armée had a short rest in late December 1812 (Larrey, 1817; Noël, 1895). 
In July-August 2006, salvage excavations due to construction were conducted in the center of Kaliningrad by a team form the Department of Salvage Archaeology (Institute of Archaeology, Russian Academy of Sciences) under the supervision of Alexander Khokhlov (Buzhilova et al., 2009). In addition to the discovery of fortifications of the old city of Königsberg, the capital of Eastern Prussia, twelve mass graves containing the remains of at least 600 individuals were discovered. The skeletons were associated with military buttons, remains of textiles, shakos, shoes, boots and coins that led to identification these remains as those of Napoleonic soldiers of the Grande Armée. This archeological and anthropological material was studied under the auspices of the CNRS French-Russian Laboratory (LIA K1812, CNRS-RAS / EPHE-Moscow State University).

The skeletal remains of soldiers revealed 103 instances of violence-related trauma, including fractures, weapon wounds and evidence of field surgery such as amputations (Dutour and Buzhilova, 2013). Among these cases, Individual 2 from Pit C (C2) exhibits a serious wound in the lower part of his face, which is the subject of this study. The 3D method of virtual reconstruction was employed in order to: (1) to understand the trauma etiology, (2) to virtually reconstruct the missing parts of the facial bones to restore the entire facial skeleton and (3) to provide a facial approximation.

\section{Material and methods}

In pit C, 26 skeletons were identified. All the individuals but two were young adult males. Their corpses had been buried directly in the ground, except one, which was buried in a wooden coffin (Buzhilova et al, 2009; Dutour \& Buzhilova, 2013). There was no particular organization in the deposit of the skeletons, but in the lower layer, the coffin and some skeletons were placed along a North/South axis with the head oriented towards the North. In 
the upper layer, the skeletons were positioned perpendicular to the coffin in a foot-to-foot position. There was no preferential burial position (figure 1). Skeleton C2, was identified as that of a young male (about 20-25 years old; following Buikstra and Ubelaker (1994) method), showing a serious wound in the lower part of his face (figure 2): this injury fractured the left side of the mandible, the maxillary bones and anterior teeth (Dutour and Buzhilova, 2013). Sex determination was based on the visual discriminant method of the ossa coxae (Bruzek 2002) and the probabilistic method developed by Coqueugniot et al. (2010) for estimating age-at-death, which combines sites and stages of epiphyseal fusion. A computer tomographic scan of the cranium and mandible was performed at the Department of Radiology of Moscow State University by one of us (A. V.) on a Philips Brilliance 64 device, using a 512 x 512 matrix, a slice thickness of $0.47 \mathrm{~mm}$, an exposure time of $780 \mathrm{~ms}$, and a Xray tube current of $128 \mathrm{~mA}$. CT data were analyzed using TIVMI® software, developed by Dutailly et al. (2009). TIVMI® has demonstrated an accuracy comparable to other 3D reconstruction software (Guyomarc'h et al. 2012) as it uses the HMH algorithm (Spoor et al. 1993) extended to 3D.

The first step of this procedure produced a semi-automatic segmentation based on the different densities of skeletal tissues: cortical bone, trabecular bone, teeth and remodeled bone corresponding to callus formation. We named 'remodeling bone' this newly formed bone tissue (so-called callus) corresponding to a healing process still in progress at the time of death. It clearly differs on the CT-slices in its density and structure from the more mature bone. These segmented slices were then converted by TIVMI in a 3D model of the cranium and mandible as it appeared at its discovery. The precision of TIVMI was crucial to the successful completion of this step. The pre-traumatic state was reconstructed by using TIVMI ${ }^{\circ}$ and Geomagic Studio ${ }^{\circledR}$ softwares. It required the removal of the actively remodeling bone and replacing fragments in their pre-traumatic anatomical positions. In some 
highly fragmented areas, the process of bone remodeling affected cortical bone. The irregularities of cortical surface associated with displacement of bone splinters, were revealed only after the segmentation and 3D reconstruction. A virtual osteotomy was performed in order to remove these irregularities. The level of the osteotomy was determined by superimposing the affected side on a mirror image of the unaffected side, which served as a guide for removal of these irregularities.

The missing parts were recreated using two techniques: by symmetry when possible (mirror imaging, Gunz et al. 2009) or by using a reference individual (virtual bone transplant) when the anatomical region was missing from both sides of the facial skeleton. For the application of the latter technique, the CT scan of a 22-year-old French man was used. The data had been anonymized, with only the age and sex of the individual being known. Craniofacial CT-scans of this individual had been performed for medical reasons other than trauma or masticatory pathology. Facial approximation was performed using TIVMI® and the AFA3D plug-in. The software uses geometric morphometrics and statistical models to estimate facial soft tissue depth and facial shape. Seventy-eight bone landmarks were used to estimate 100 cutaneous landmarks. The software database consists of a reference sample composed of 500 CT-scan of adults (of which 265 are males) from several hospitals in France. Age, sex and body mass can be estimated (Guyomarc'h et al., 2014). Phenotypic details were added using the software Blender®. Eye color, hair and skin pigmentation were selected based on those representing the most common phenotypes noted in the military registers of the Napoleonic regiments (Degioanni, 2012). The uniform corresponds to one of the regiments identified in the pits due to the presence of military buttons.

\section{Results}


The male sex was confirmed and the age-at-death was estimated with a probability of $98 \%$ as belonging to the 24-27 year-old age category. Therefore, this result places this individual's birth between 1785 and 1788- that is to say, before the French Revolution.

\section{Paleotraumatological description}

The mandible consists of two main fragments: the right ramus and a large part of the symphysial region attached to the left side of the bone. Most of the right mandibular corpus from the first premolar to the ramus is missing. A fracture callus can be seen in the inferior and lateral parts of the right ramus. The CT-scan images permitted identification of five osseous fragments by separating them from the bone callus. Three of these fragments from the inferior region were not in their anatomic position, being displaced laterally or medially. In this area, the remodeling bone is strongly developed, completely surrounding these bone fragments. The outline of this callus is not perfectly smooth. The segmentation of CT-scan images also confirmed that the entire lateral side of the ramus was affected by remodeling processes, even the superior part, far from the lesion.

A fracture between the left side and the symphysis region can be seen in the main fragment. The 3D images revealed a third fragment, surrounded by remodeling bone on the lingual side of the symphysial region. The bone healing process seems much more advanced around this small fragment than around the main fracture on the left side of the mandible. The remodeling processes affect mainly the trabecular bone in this region (Figure 3).

All teeth, except the three left molars, are missing. The dental alveoli do not show any evidence of bone remodeling. A part of the right maxilla and the anterior teeth (incisors, canines and right premolars) are missing. The trauma impacted the maxillary body, the alveolar and palatine processes. The frontal and the zygomatic processes remain relatively unaffected. The segmentation of this region did not permit identification of any fragments 
within the new bone formation. The first left premolar is broken, with an oblique anteroposterior and downward fracture; the root is still visible in the dental alveolus. The second left premolar was initially present but fell out during the lab study.

Re-examination of the field photographs show that most of this missing maxillary fragment was originally in place during excavation (Figure 1). This bone fragment was probably misallocated when skeletons were rapidly removed due to time pressure imposed by the real estate developer in the context of a rescue excavation (Dutour and Buzhilova, 2013). The fragment was not present among the bags of remains during the lab study performed at the Museum of Kaliningrad in September 2006 (Dutour, pers. com.).

The remodeling process in the remaining right maxilla is poorly developed, and may correspond to a healing without a great gap (Marsell and Einhorn, 2011) between the traumatic event and death. The nasal bones are not present; the breakage in this region corresponds to recent postmortem break (Lovell, 1997; Marin-Monfort et al., 2017). The nasal aperture is deviated to the right, while the perpendicular plate of the ethmoid is deviated to the left. No others parts of the upper face seem to be affected by traumatic or taphonomic processes. No other particular marks are visible on the cranium and no remains of weapons, such as lead bullets or blade fragments, are present.

\section{Reconstruction of the pre-traumatic state}

The fragments of the symphysis and left side of the mandible were correctly positioned and re-assembled after the removal of the newly formed bone of the callus. A virtual osteotomy was performed on the inferior part of the right ramus (inferior to the mandibular foramen). Indeed, this part of the bone was much remodeled and distorted due to the poor re-positioning of the fragments following the traumatic episode. The right corpus was recreated by mirrorimaging using the preserved left side of the mandible (Figure 4). The reconstruction of the 
maxilla was not possible using mirror imaging. Indeed, no preserved part could be used to recreate the missing ones. To overcome this obstacle, clinical CT data from a young French man of similar maxillary size and robustness and comparable age (22 years old) was virtually transplanted into the portion of his maxilla corresponding to missing part of soldier's face (Figure 5). These 3D reconstruction and restoration processes of the mandible and maxilla allowed us to obtain a virtual complete skull (Figure 6). Therefore, it has been possible to perform an approximation of the individual's face using the AFA3D software. This provides a neutral facial model (Figure 7A). Upon completion of this procedure, the resulting facial approximation was further enhanced with the addition of realistic pigmentation and texture details using Blender software (Figure 7B).

\section{Discussion}

The facial lesions of this individual affecting both the mandibular and maxillary bones correspond to severe facial trauma. The presence of sharp force trauma excludes a simple accidental cause. The victim was probably wounded during a fight against Russian troops. Violence-related traumatic injuries can be due to various weapons, including firearms (rifles and pistols), cannons, and edged weapons such as sabers. These lesions do not correspond to a firearm injury as no metallic artefacts, such as lead shot, were identified (Coqueugniot et al., 2015).

Therefore, the most probable weapon that produces this type of trauma is the heavy saber used by cavalry of the period. The maxillary fracture detached bone without any fragmentation, contrary to the mandible which was broken in several pieces. Thus, the maxilla was the area of intial impact, cutting off the anterior part of the maxillary process just inferior to the nasal aperture. Secondarily, the loss of velocity and energy caused by striking the 
maxilla produced a major fracture of the right mandibular corpus. The fracture on the left side of the mandible may correspond to a balancing fracture resulting from the violent blow (Lovell, 1997). The force of the blow would be increased by the speed at which two mounted soldiers would clash. Bilateral extension of the articular surface is observed on the anterior surface of the femoral neck of this individual, a feature that is observed among $25 \%$ of the femora in this series (Dutour and Buzhilova, 2013), and that has been proposed as a skeletal indicator of horse-riding by some authors (Palfi, 1992; Molleson and Blondiaux, 1994; Palfi and Dutour, 1996, Baillif-Ducros et al, 2012; McGrath, 2015), even if this interpretation was questioned by other scholars (Radi et al, 2013).

It is difficult to determine the hand preference of the assailant. As the left side of the victim is affected, one possible scenario would be that the wound was received in a face-toface confrontation with a left-handed opponent. However, the trajectory of the blow, from superior to inferior and slightly posteriorly, would better correspond with a blow delivered by a right-handed assailant who was on the left side of the victim. In this case, the lesion would correspond to a saber blow of the "taille", the blade of the sword. At this time in history, the "estoc" (with the tip of the sword) was the recommended part of the sword to wound an enemy combatant (de Brack, 1876). The "taille" causing extensive but superficial cuts, contrary to the "estoc" which causes smaller but deeper wounds but penetrates to reach vital organs. This kind of facial saber blow has been reported during the Russian campaign (Larrey, 1812; Noël, 1895).

The saber hypothesis is supported by the general appearance of the lesion and by the fracture angle on the left maxillary premolar, the same as that observed on the mandible. Soft tissues served as flaps that kept bone fragments in place. A very similar case of a facial wound caused by a saber occurred during the Russian Campaign, as described by Dominique Larrey, French surgeon in chief of the Grande Armée (Larrey, 1817). The patient, a Russian colonel, 
saber-wounded during conflict with a French cavalryman, presented with a maxillary fracture, dental loss and severe soft tissue lesions of the nose and mouth: "Then I detached the portion of the palatal vault that held to the flap [of soft tissue]. It consisted of the anterior half of the upper alveolar arch. It had been separated from the rest of the jaw, on one side, between the canine and the first premolar, and, on the other, between the first two molars"1.

To remedy this damage, Larrey recommended a precise procedure he had experimented several times with success: extraction of all the small bone fragments, mandibular fracture immobilization by means of external fixation (dental braces) and reconstruction of soft tissues by suture stitches (Larrey, 1812, 1817; Ferret-Dussart, 2004).

Remodeling processes observed on the maxilla and mandible show that this wound was severe but not immediately lethal. The firm attachment of the callus to the cortex, the relative smoothing of its outline and the incompleteness of the healing indicates that the victim survived between 6 weeks and 3 months after the trauma according to a method of determination of post-traumatic time interval (De Boer et al., 2015). Therefore it is most probable that the victim has been taken into care in one of the French military hospitals of Königsberg (Larrey, 1817; Noel, 1895), and treated according to the Larrey's surgical procedure. It should be noted that pits were located close to one of the French military hospitals of Königsberg (Buzhilova et al, 2009). This wounded soldier was on the way to recovery when he died, possibly from a co-morbid cause.

Epidemic outbreaks of typhus (Rickettsia prowazecki) and trench fever (Bartonella quintana) occurred in Königsberg in late 1812-early 1813 (Ozanam, 1835). Molecular biology

\footnotetext{
${ }^{11}$ «Je détachai ensuite la portion de la voûte palatine qui tenait au lambeau. Elle se composait de la moitié antérieure de l'arcade alvéolaire supérieure. Elle avait été séparée du reste de la mâchoire, d'un côté, entre la canine et la première prémolaire, et, de l'autre, entre les deux premières molaires » (Larrey, 1817)
} 
has confirmed the presence of these two diseases in Vilnius (Raoult et al. 2006), a city located along the road to Königsberg. The poor physiological state due to having sustained a severe wound and consequent eating difficulties of this wounded combatant in the exhausting retreat and the extremely cold temperature may have been significant aggravating factors in his demise.

\section{Conclusions}

The virtual study of a traumatic injury using computed-tomodensitometry furthers understanding of a bone lesion, its causes and consequences. Study of CT-scan slices makes it possible to better observe the different tissues and thus better understand the blow. Moreover permits estimation of the post-traumatic survival time. As a complement to $2 \mathrm{D}$ analysis, this study demonstrates the value of $3 \mathrm{D}$ reconstruction of the mandible and the maxilla through the application of two original techniques: virtual osteotomy and virtual bone transplant. They permit reconstruction of the pre-traumatic state of the cranium and mandible. These two, easy to apply techniques differ from those commonly used in paleoanthropology (Gunz et al., 2009) but accurately approximate facial features. More than two centuries after his death, this facial reconstruction brings this unknown soldier's face back to the present.

\section{Acknowledgements}

We thanks Pr. Christopher J. Knüsel for the English editing and his suggestions. We also thanks the three anonymous reviewer for their comments and recommendations to improve the quality of the manuscript.

\section{Funding}


The research project was supported by the CNRS and the Russian Academy of Sciences under the auspices of the French-Russian Laboratory (LIA K1812, Anthropology and Archaeology of the Retreat of Russia, directed by Olivier Dutour and Alexandra Buzhilova)

The present study was supported by the Nouvelle-Aquitaine Regional Council in the framework of the project VIRTOS (virtothèque ostéologique de Bordeaux, directed by Olivier Dutour).

\section{Bibliography}

Baillif-Ducros C., Truc M.C., Paresys C., Villotte S. 2012. Approche méthodologique pour distinguer un ensemble lésionnel fiable de la pratique cavalière. Exemple du squelette de la tombe $11 \mathrm{du}$ site de «La Tuilerie » à Saint-Dizier (Haute-Marne), VIe siècle. Bulletins et Mémoires de la Société d'Anthropologie de Paris 24: 25-36. DOI:10.1007/s13219-011-0049-8

Boudon J-O, 2012, Lettres de la campagne de Russie, 1812, ed. Pierre de Taillac, Paris, 320p.

Bruzek J. 2002. A method for visual determination of sex, using the human hip bone. American Journal of Physical Anthropology 117: 157-168.

Buikstra J. E. and Ubelaker D., 1994. Standards for data collection from human skeletal remains. Research series no. 44. Fayetteville, Arkansas: Arkansas archeological survey research series no 44. 272p.

Buzhilova A., Rigeade C., Shvedchikova T., Ardagna Y., Dutour O., 2009 The discovery of a mass grave of Napoleon's great army in Kaliningrad (formerly Königsberg), Russian Federation: preliminary results and interpretations. Luc Buchet, Catherine Rigeade, Isabelle Séguy et Michel Signoli (dir), 9e journées d'anthropologie de Valbonne, 2008, Antibes, France. Editions ADPCA, 375-383

Coqueugniot H., Weaver T.D., Houët F., 2010. A probabilistic approach to age estimation from infracranial sequences of maturation. American Journal of Physical Anthropology, 142: 655-664.

Coqueugniot H., Dutailly B., Desbarats P., Buzhilova A.P., Dutour O., 2015. Développement des virtothèques ostéologiques en anthropologie biologique et en paléopathologie. Application aux traumatismes de guerre de la période napoléonienne (Retraite de Russie, décembre 1812), première analyse virtuelle de paléo-balistique. Actes du Colloque Virtual Retrospect 2013, Collection Archéovision, volume 6, Ausonius Editions: 57 - 62.

De Beauchamp A., 1825. Mémoires secrets et inédits pour servir à l'histoire contemporaine, tome 2, ed. Vernarel et Tenon, Paris, 363p. 
De Boer, H.H., Van Der Merwe, A.E., Hammer, S., Steyn, M., Maat, G.J.R., 2015. Assessing post-traumatic time interval in human dry bone. International Journal of Osteoarchaeology 25: $98-109$

De Brack A.F., 1876. Light cavalry out-posts: Recollections by F. De Brack, translated from the fifth edition for F.M. The marquis of Tweeddale, ed. by Lonsdale A. Hale and F.T. Hobson (London: W. Mitchell \& Co. Military Publishers), 308 p.

Degioanni A., 2012. Phenotypic and Patronymic data in the Napoleonic Great Army and the Russian Campaign, preliminary results from historical archives (Musée de l'Armée, Chateau de Vincennes). Bicentennial Anniversary Workshop, December 1812 - December 2012, Anthropology and Archaeology of the Russian Napoleonic Campaign, Moscow, December 6th-9th, 2012 (oral communication).

Dutailly B, Coqueugniot H, Desbarats P, Gueorguieva S, Synave R 2009. 3D surface reconstruction using HMH algorithm. Proceedings of the 16th IEEE International Conference on Image Processing, 2505-2508.

Dutour O., 2002. Traces de vies disparues, Socio-anthropologie, 12: 1-6.

Dutour O. and Buzhilova A., 2013. Paleopathological study of Napoleonic mass graves discovered in Russia. In: Knüsel C.J., Smith, M.J. (eds.) The Routledge Handbook of the Bioarchaeology of Human Conflict, $706 \mathrm{p}$

Dutour O., Buzhilova A., Jankauskas R., 2014. Paléopathologie de la guerre: l'exemple de la Campagne de Russie. In: O. Buchsenschutz, O. Dutour, C. Mordant (eds), Archéologie de la violence et de la guerre dans les sociétés pré et protohistoriques, Paris: Editions du CTHS.

Dutour O., Jankauskas R., Buzhilova A., 2015. Ensembles funéraires liés à des faits de guerre. In Courtaud P., Romon T., Kacki S., Cimetières et identités. Editions Ausonius : 133-145

Ferret-Dussart K, 2004. La chirurgie maxillo-faciale à travers l'histoire. Editions Glyphe \& Biotem. 363 p.

Gunz, P., Mitteroecker, P., Neubauer, S., Weber, G.W., Bookstein, F.L., 2009. Principles for the virtual reconstruction of hominin crania. Journal of Human Evolution 57: 48-62

Guyomarc'h P., Santos F., Dutailly B., Desbarats P., Bou C., Coqueugniot H., 2012. Threedimensional computer-assisted craniometrics: A comparison of the uncertainty in measurement induced by surface reconstruction performed by two computer programs, In Forensic Science International, 219, Issues 1-3: 221-227, doi.org/10.1016/j.forsciint.2012.01.008

Guyomarc'h, P., Dutailly, B., Charton, J., Santos, F., Desbarats, P. and Coqueugniot, H. 2014. Anthropological Facial Approximation in Three Dimensions (AFA3D): Computer-Assisted Estimation of the Facial Morphology Using Geometric Morphometrics. Journal of Forensic Science, 59: 1502-1516.

Larrey, D.J. 1812. Mémoires de chirurgie militaire et campagnes, tome II, Paris: Chez J. Smith, $513 \mathrm{p}$.

Larrey, D.J. 1817. Mémoires de chirurgie militaire et campagnes, tome IV, Paris: Chez J. Smith, $518 \mathrm{p}$. 
Lovell, N. 1997. Trauma Analysis in Paleopathology, Yearbook of Physical Anthropology, 40: $139-170$.

McGrath M.S. 2015. A review of the archaeological and sports medicine literature to determine the biomechanical markers of equestrian activity. University of New Brunswick, Academia.edu. Retrieved from http://www.academia.edu/12094909

Marin-Monfort M.D., Suñer M., Fernandez-Jalvo Y. 2017. Characterization of recent marks produced on fossil bone surface during sullegic and trephic processes and their influence on taphonomic studies. Quaternary International, https://doi.org/10.1016/j.quaint.2017.07.039.

Marsell R. and Einhorn T., 2011. The biology of fracture healing. Injury, 42 (6): 551-555.

Molleson T., Blondiaux J. 1994. Riders' Bones from Kish, Iraq. Cambridge Archaeological Journal 4: 312-316. DOI:10.1017/S095977430000113X

Noël, J. N. A., 1895. Souvenir militaire d'un officier du Premier Empire (1795-1832). Paris: Librairie des Deux Empires.

Pálfi G. 1992. Traces des activités sur les squelettes des anciens Hongrois. Bulletins et Mémoires de la Société d'Anthropologie de Paris 4: 209-231. DOI:10.3406/bmsap.1992.2318

Pálfi, G., Dutour, O., 1996. Activity-induced skeletal markers in historical anthropological material. International Journal of Anthropology, 11: 41-55.

Radi, N. , Mariotti, V. , Riga, A. , Zampetti, S. , Villa, C. and Belcastro, M. G. 2013. Variation of the anterior aspect of the femoral head-neck junction in a modern human identified skeletal collection. American Journal of Physical Anthropology, 152: 261-272. doi:10.1002/ajpa.22354

Raoult D., Dutour O., Houmamdi L., Jankauskas P.-E., Ardagna Y., Drancourt M., Signoli M., La V.-D., Macia Y., Et Aboudharam G., 2006. "Evidence for louse-transmitted diseases in soldiers of napoléon's grand army in Vilnius", Journal of Infectious Diseases, 193(1): 112120

Signoli, M., Ardagna, Y., Adalian, P., Devriendt, W., Lalys, L., Rigeade, C., Vette, T., Kuncevicius, A., Poskiene, J., Barkus, A., Palubeckaité, Z., Garmus, A., Pugaciauskas, V., Jankauskas, R., Dutour, O., 2004. Discovery of a mass grave of Napoleonic period in Lithuania (1812, Vilnius). Comptes Rendus Palevol. 3: 219-227.

Signoli M., Vette Th., Dutour O., Ardagna Y., 2008. Les Oubliés de la Retraite de Russie; Vilna 1812-Vilnius 2002, Libraire Historique Teissedre Paris, 178p.

Spoor C.F., Zonneveld F.W., Macho G.A., 1993. Linear measurements of cortical bone and dental enamel by computed tomography: applications and problems. American Journal of Physical Anthropology 91: 469-484. 


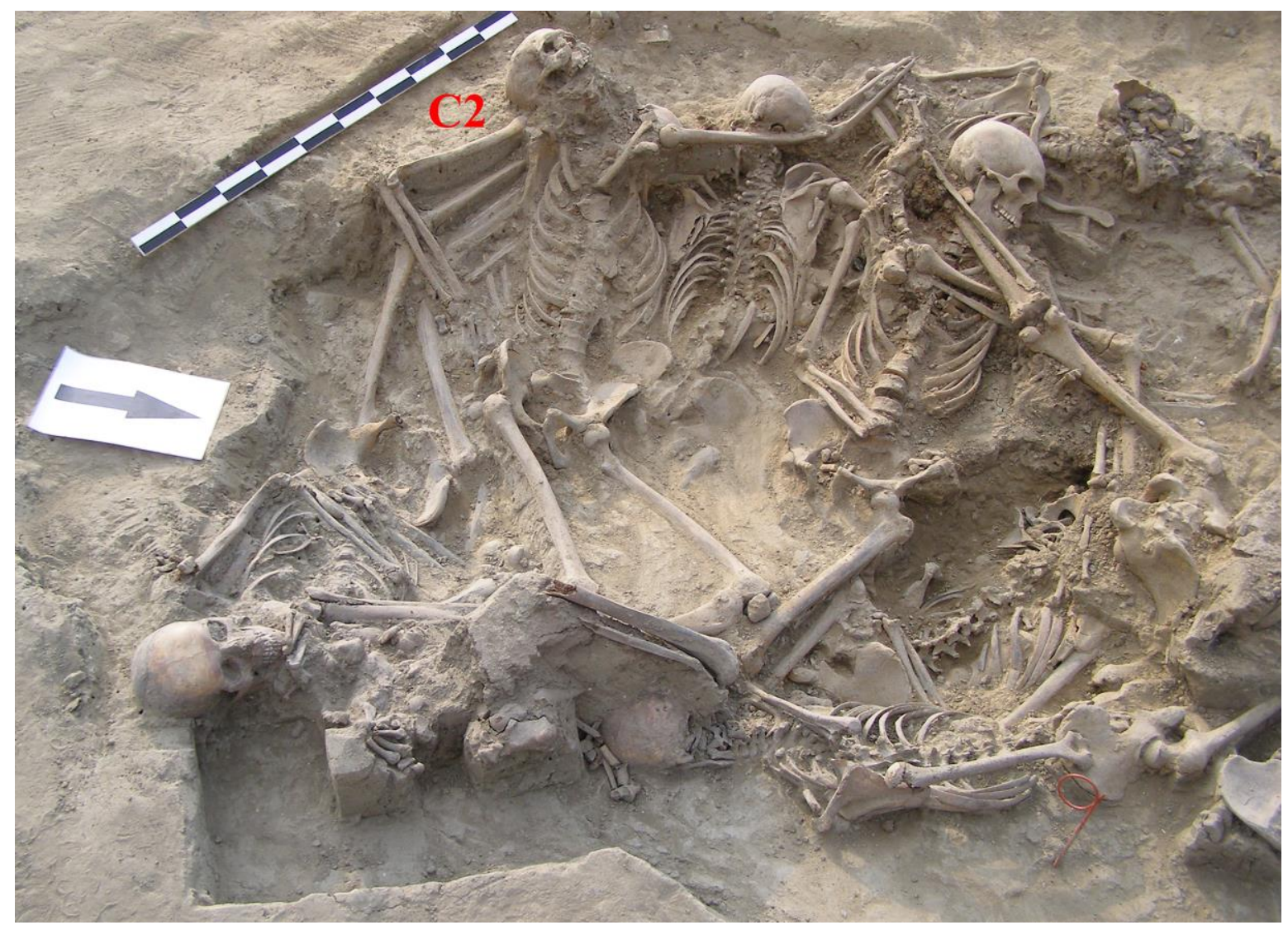

Figure 1

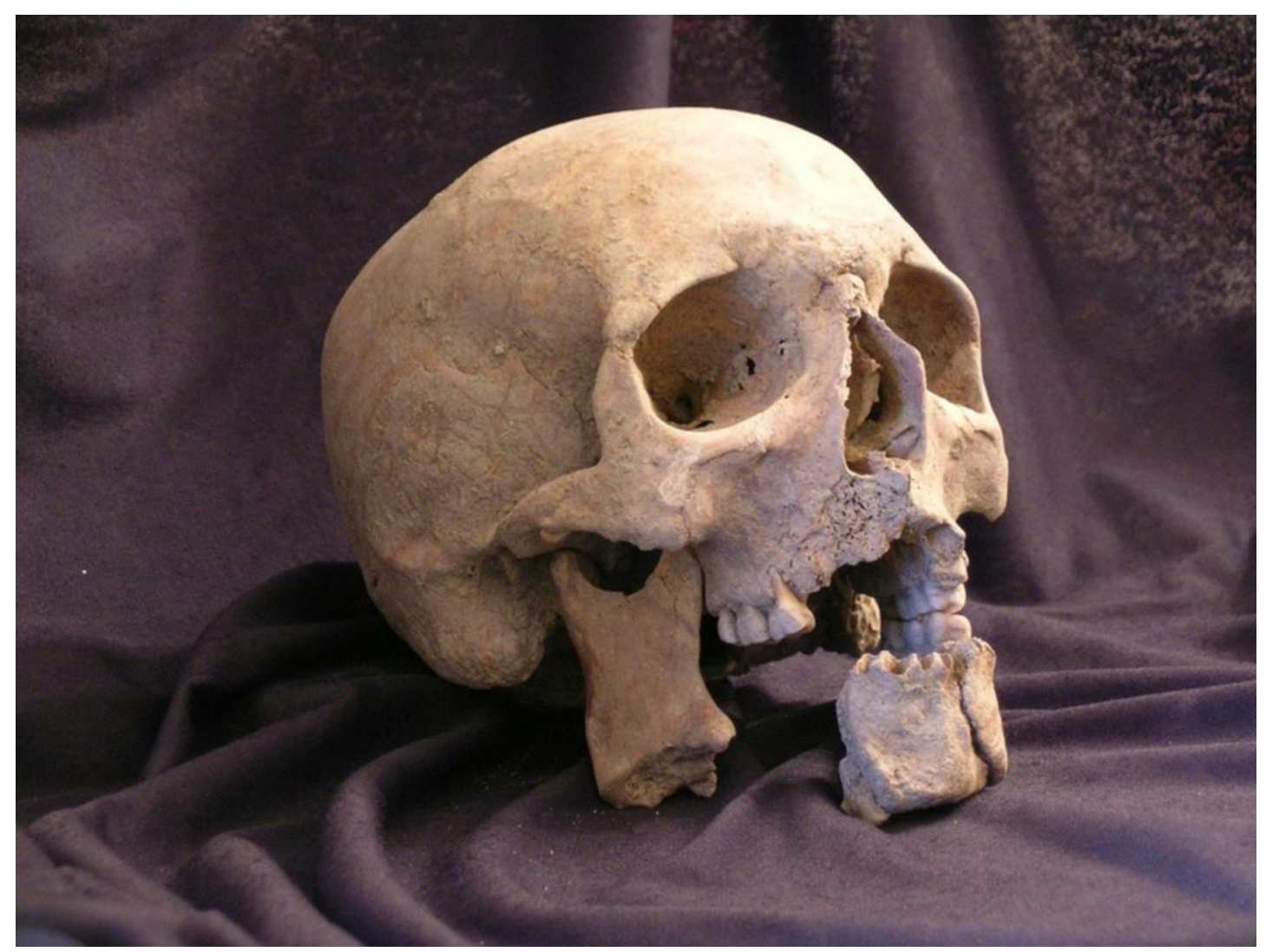

Figure 2 


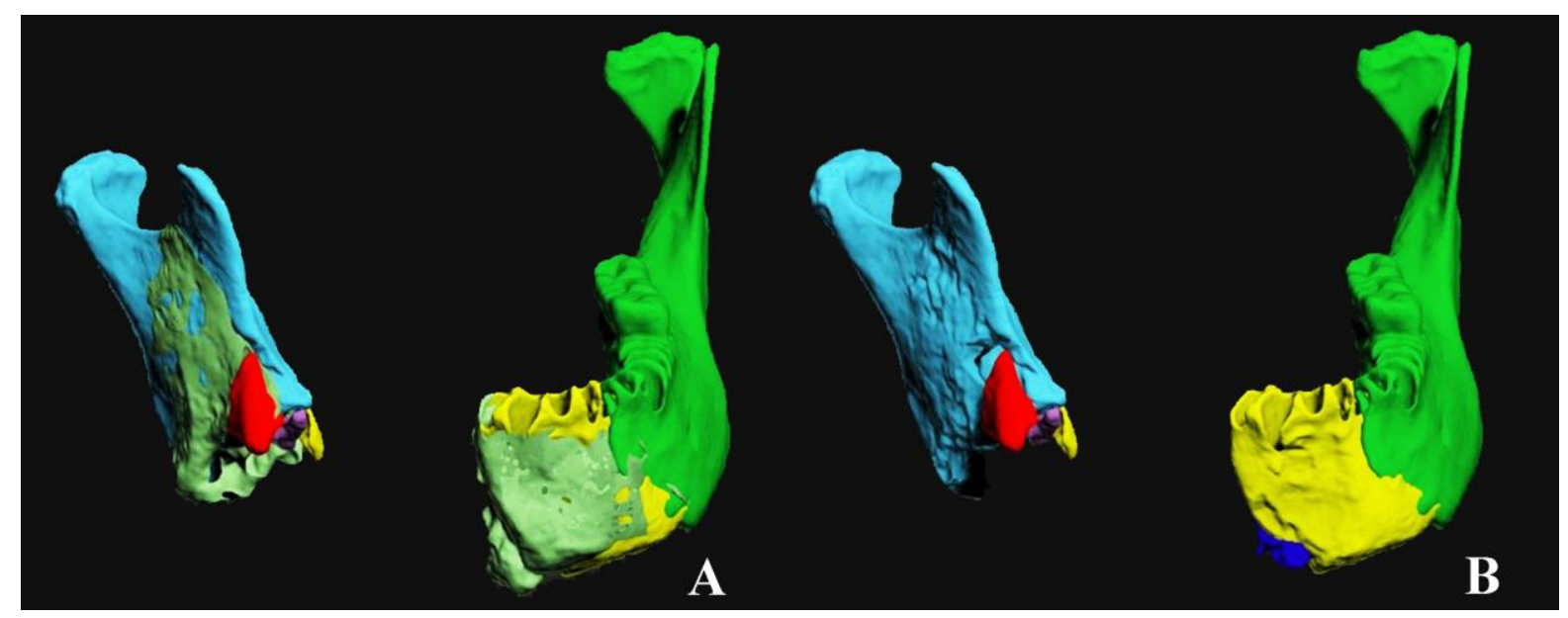

Figure 3

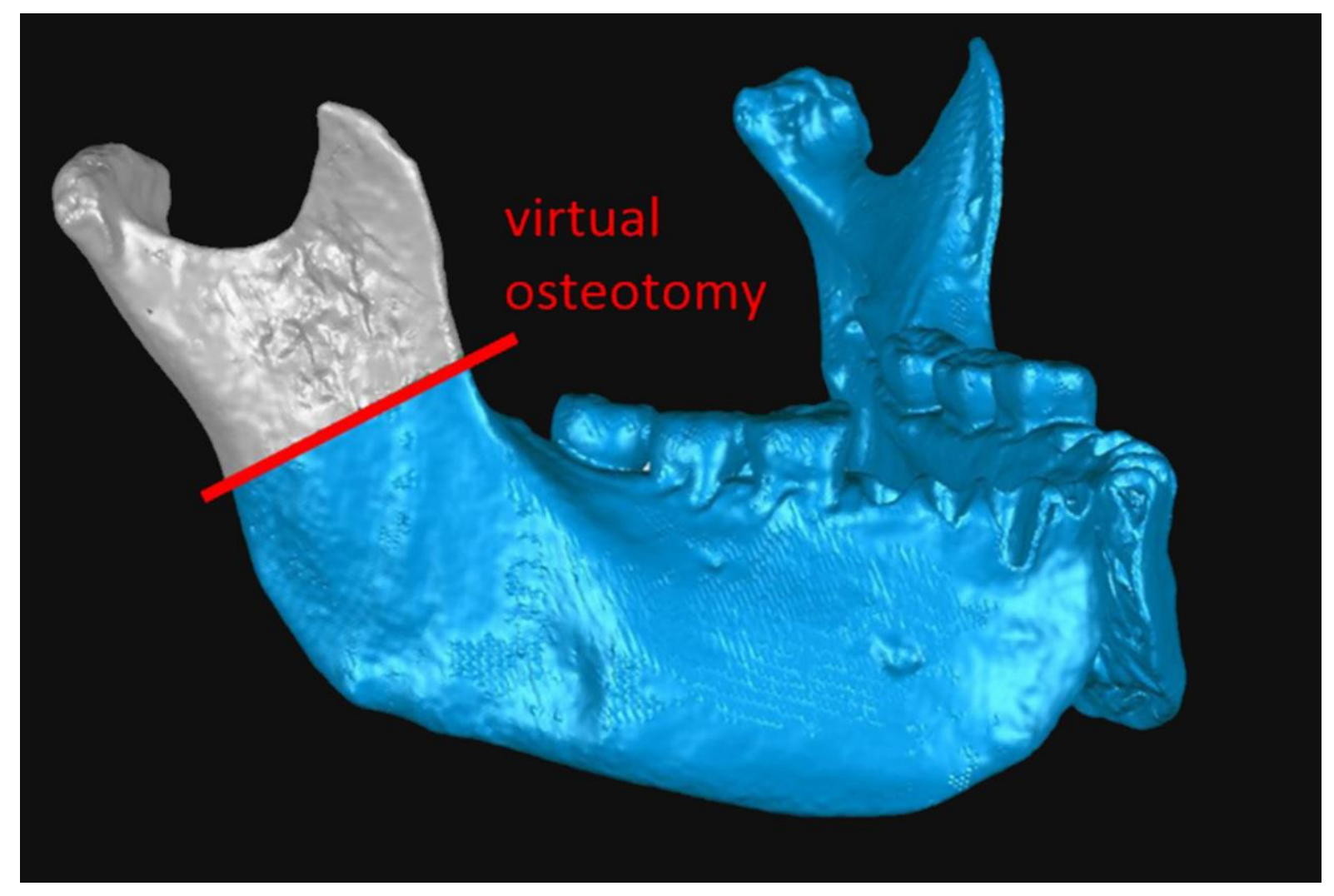

Figure 4 


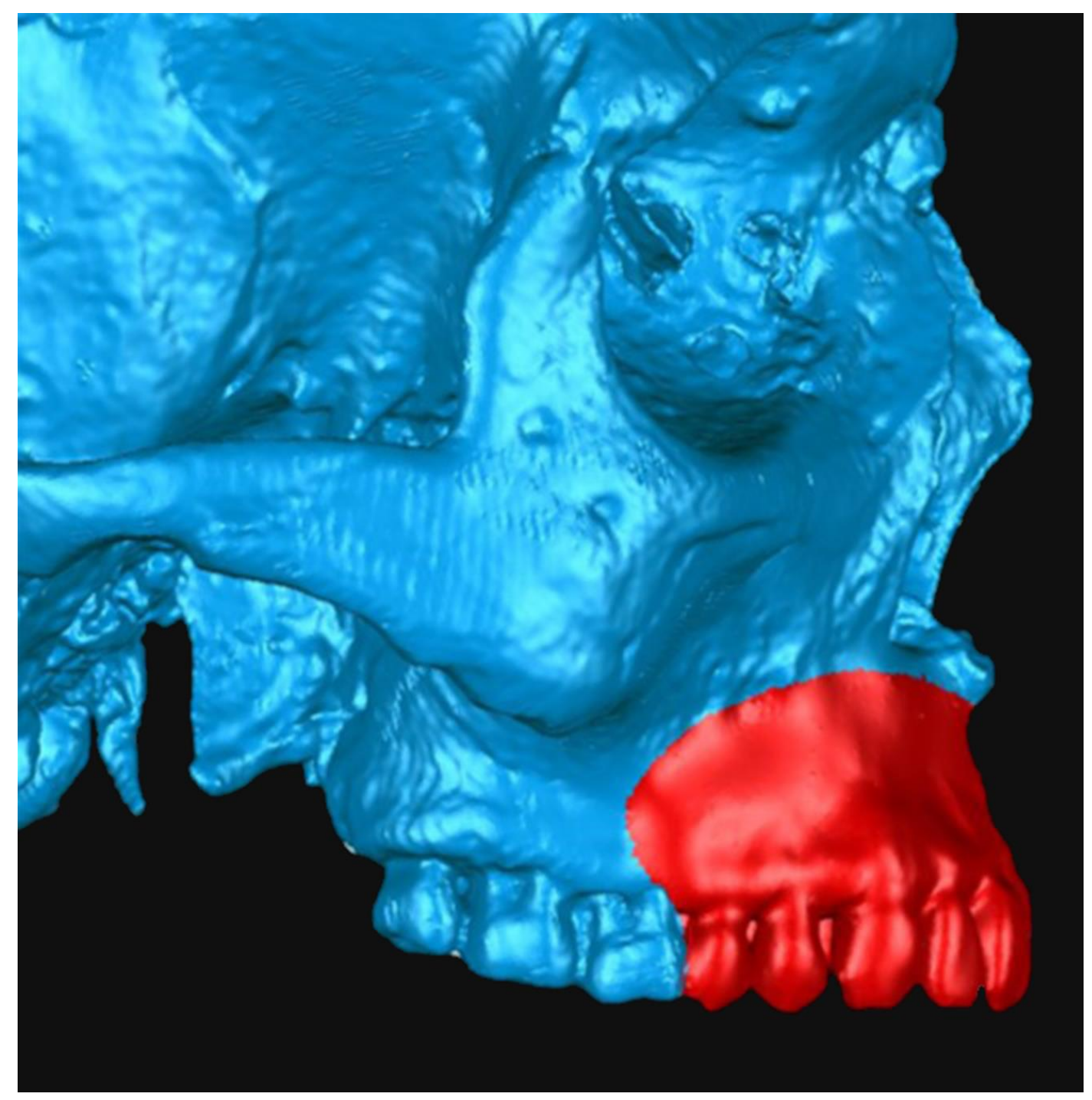

Figure 5 


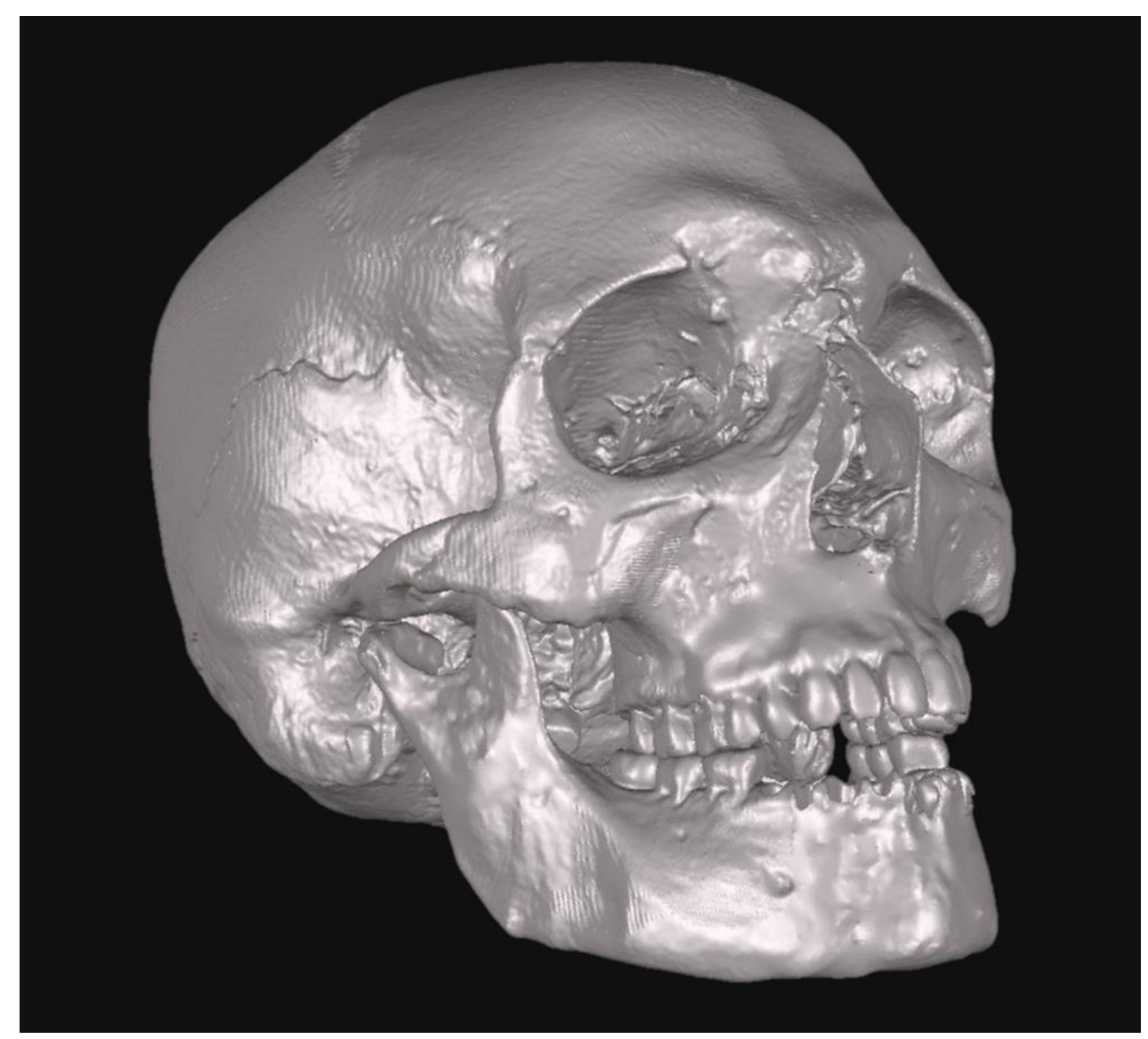

Figure 6

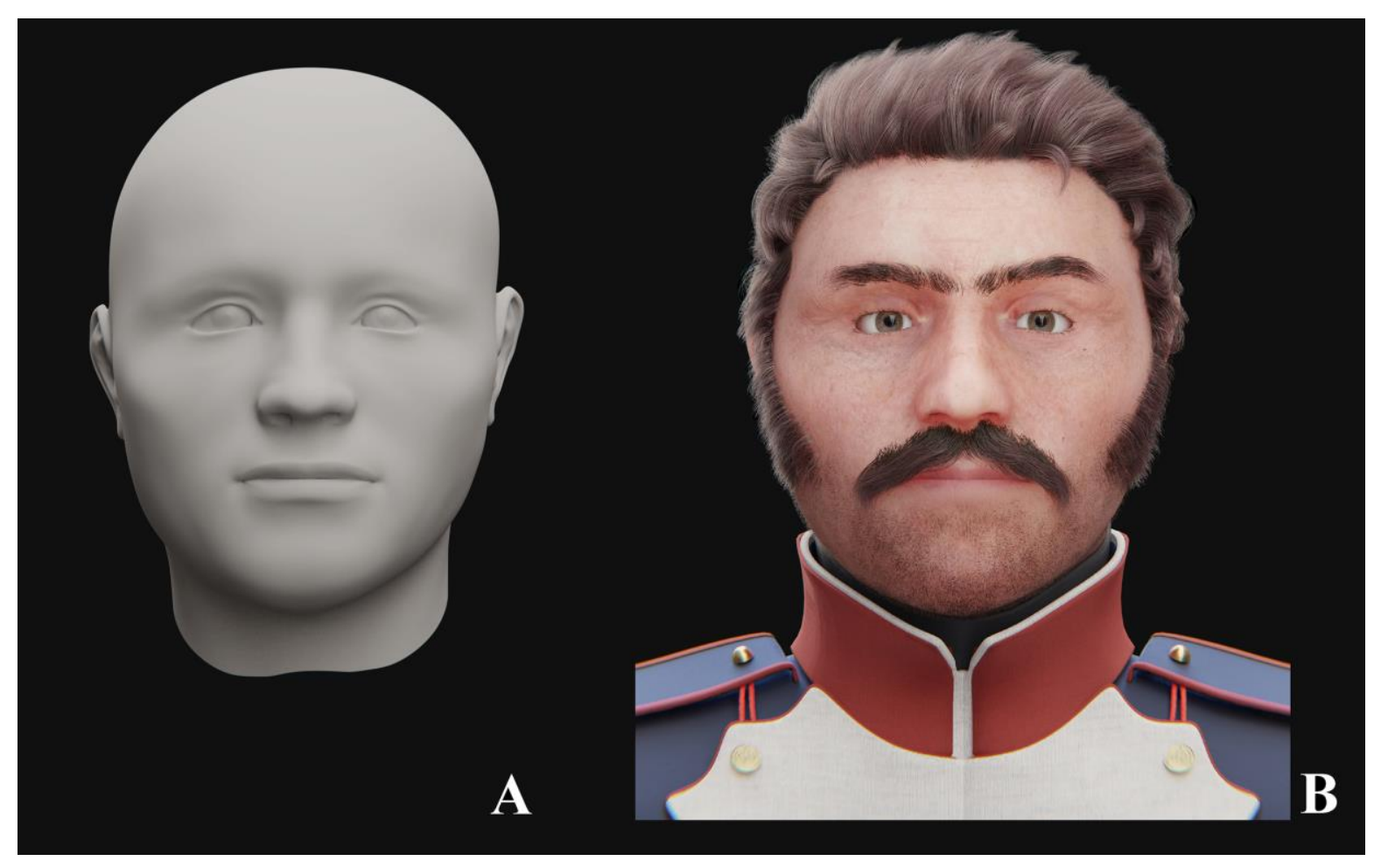

Figure 7 